\title{
PENGEMBANGAN MODEL LATIHAN PASING BAWAH KLUB BOLAVOLI IKIP BUDI UTOMO MALANG
}

\author{
Moh. Ali Mu'arifuddin \\ Program Studi Pendidikan Jasmani, Kesehatan, dan Rekreasi \\ IKIP Budi Utomo Malang \\ E-mail: aliamzeta@gmail.com
}

Diterima: 14 Juli 2018; Lolos: 12 Oktober 2018; Dipublikasikan: 24 Oktober 2018

DOI: https://doi.org/10.29407/js_unpgri.v4i2.12236

\begin{abstract}
Abstrak
Tujuan penelitian ini untuk mengembangkan model latihan pasing bawah pada Tim Bolavoli IKIP Budi Utomo Malang. Metode penelitian yang digunakan adalah model pengembangan research and development Borg and Gall. Hasil analisis persentase data dari uji validasi ahli diperoleh sejumlah $87,75 \%$ dengan kategori valid untuk ahli bolavoli dan 94,75\% dengan kategori valid untuk ahli media, sehingga dinyatakan valid dan dapat digunakan pada Tim Bolavoli IKIP Budi Utomo. Hasil uji lapangan pada kelompok kecil dengan subjek 8 Pemain diperoleh persentase $87,63 \%$ dengan kategori valid dan uji coba kelompok besar dengan subjek 20 Pemain diperoleh persentase sebesar 91,41\% dengan kategori valid. Berdasarkan hasil validasi ahli dan uji lapangan, dapat disimpulkan bahwa model latihan pasing bawah bolavoli ini valid dan dapat digunakan pada Tim Bolavoli IKIP Budi Utomo Malang.
\end{abstract}

Kata kunci: Model latihan, pasing bawah, bolavoli.

\section{DEVELOPMENT THE MODEL OF UNDERHAND SERVICE TRAINING ON IKIP BUDI UTOMO MALANG VOLLEYBALL TEAM}

\begin{abstract}
The purpose of this research to develop the model of underhand service training on IKIP Budi Utomo Malang Volleyball Team. The research method in this research is research and development research model of Borg and Gall. The results of the data percentage analysis from the expert validation test obtained $87.75 \%$ with valid categories for volleyball experts and $94.75 \%$ with valid categories for media experts, so that it was declared valid and it can be used on IKIP Budi Utomo Volleyball Team. The results of field tests in small groups with 8 Players obtained of $87.63 \%$ with valid categories and field tests in large groups with 20 Players obtained of $91.41 \%$ with valid categories and it can be used. Based on the results of expert validation and field testing, it can be concluded that this volleyball underhand training model is valid and can be used on IKIP Budi Utomo Malang Volleyball Team.
\end{abstract}

Keywords: The model of exercise, underhand pass, volleyball.

\section{PENDAHULUAN}

Cabang olahraga bolavoli merupakan olahraga yang digemari oleh masyarakat Indonesia baik laki-laki dan perempuan. Permainan bolavoli 
adalah permainan beregu yang dimainkan oleh dua tim dan setiap tim terdiri dari enam pemain (Muttaqin, Winarno, \& Kuniawan, 2016). Bolavoli adalah permainan yang dilakukan oleh dua regu saling berhadapan yang dipisahkan dengan jaring dan setiap regu terdiri dari enam orang (Hasmara, 2017). Permainan bolavoli merupakan suatu permainan yang kompleks yang tidak mudah untuk dilakukan setiap orang (Rosdiani, 2012). Dikatakan sebagai permainan yang kompleks karena di dalam permainan bolavoli terdapat komponen teknik, fisik, strategi dan taktik. Komponen teknik merupakan komponen yang harus dikuasai oleh masing-masing pemain Tim. Teknik dasar bolavoli terdiri atas bermacammacam gerakan (Hidayat, 2015). Teknik dasar permainan bolavoli yaitu, servis, passing, smash, dan block. Servis terbagi menjadi dua yaitu, servis bawah dan servis atas, passing juga di bagi menjadi dua, yaitu passing bawah dan passing atas (Iskandar \& Yulianingsih, 2015). Penguasaan teknik sangat diperlukan dalam melakukan permainan bolavoli dan teknik dasar pasing bawah menjadi teknik yang paling penting dalam menyusun sebuah serangan maupun memperkuat pertahanan. Mengingat olah raga bolavoli adalah permainan beregu, maka pola kerja sama antar pemain mutlak diperlukan untuk membentuk tim yang kompak dengan demikian, penguasaan teknik-teknik dasar dalam olah raga bolavoli secara perorangan sangatlah penting untuk dikuasai (Pasaribu, 2016). Rangkaian serangan akan dapat terlaksana apabila penguasaan teknik dasar pasing para pemain sangat bagus dan akurat, karena sebagus apapun spike yang dilakukan penyerang tidak mungkin berjalan dengan maksimal apabila pasing yang dilakukan tidak akurat. Klub bolavoli IKIP Budi Utomo Malang merupakan Klub yang telah banyak mengikuti turnamen dan kejuaraan tingkat daerah maupun nasional. Menurut pelatih tim, berdasarkan evaluasi yang dilakukan setiap pertandingan ditemukan masih banyak kekurangan dalam penguasaan teknik dasar para pemain, statistik pertandingan menunjukkan kesalahan yang dilakukan pemain tim secara keseluhan disebabkan kesalahan dalam servis (9,12\%) spike/smash (14,85\%), kesalahan blok (29,68\%), kesalahan pasing atas 
$(5,12 \%)$ kesalahan pasing bawah $(41,23 \%)$, data tersebut sesuai dengan perolehan poin pada tiap pertandingan, fakta yang ditemukan berupa kesalahan yang paling banyak terjadi pada teknik dasar pasing bawah mejadi landasan peneliti dalam melakukan penelitian pengembangan.

Penyebab kehilangan poin dalam permainan yang dilakukan oleh Tim yang diteliti bukan dari serangan yang gagal atau serangan yang mampu dikembalikan oleh tim lawan, namun lebih banyak terjadi akibat kesalah pemain tim sendiri, kesalahan banyak terjadi dalam melalukan pasing bawah baik dalam rangkaian serangan maupun saat menerima serangan lawan.

Latihan yang terus menerus dan terprogram perlu dilakukan untuk memperbaiki kelemahan Tim dalam pasing bawah. Kemampuan yang dimiliki pemain tidak lepas dari latihan-latihan yang dilakukan sesuai program latihan yang diberikan pelatih tim. Melalui pembinaan dan pelatihan yang dilakukan secara sistematis dan kontinyu diharapkan memiliki keterampilan bermain bolavoli dan mampu mencapai prestasi yang tinggi (Primayanti, 2016).

\section{METODE}

Penelitian ini menggunakan pendekatan penelitian dan pengembangan. Sedangkan model pengembangan yang digunakan adalah model pengembangan Research \& Development (R\&D) dari (Gall, Gall, \& Borg, 2007). Penelitian dan pengembangan adalah suatu proses atau langkah-langkah untuk mengembangkan suatu produk baru atau menyempurnakan produk yang telah ada. Penelitian pengembangan merupakan jenis penelitian yang berorientasi pada produk dan diharapkan dapat menjembatani kesenjangan penelitian yang lebih banyak menguji teori kearah menghasilkan produk-produk yang langsung dapat digunakan oleh pengguna (Tauhidman \& Ramadan, 2018). Penelitian ini menggunakan desain pengembangan Borg and Gall yang diadaptasi dari sebelumnya berjumlah 10 tahap menjadi tujuh tahap yaitu: (1) pengumpulan data awal, (2) perencanaan, (3) Desain produk awal, (4) Uji coba awal, (5) perbaikan produk awal, (6) Uji lapangan, (7) 
Perbaikan Produk akhir (jika terdapat saran perbaikan dan dinilai diperlukan penyesuaian). Pada tahap perencanaan dan desain peneliti melakukan pengonsepan dilanjutkan dengan pengumpulan materi hingga pembuatan dan desain draft produk, pada tahap uji coba awal dilakukan uji validitas untuk memperoleh kesiapan produk sebelum dilakukan uji lapangan. Tahap validasi oleh pakar menjadi satu tahap yang penting (Safitri \& Hartati, 2016). Uji validitas meliputi validasi ahli bolavoli oleh dua orang ahli untuk mendapatkan masukan yang lebih banyak dari sumber atau validator berbeda dan validasi oleh ahli media yang dinilai cukup oleh satu orang ahli, semua ahli tersebut berkualifikasi minimal pendidikan S2 berlisensi B Pelatih Nasional Bolavoli dan ahli pada bidangnya, dilanjutkan dengan tahap perbaikan poduk awal jika draft produk awal perlu dilakukan revisi, kemudian dilakukan uji lapangan dalam skala kecil yaitu diujikan kepada sejumlah 8 pemain dan skala besar sejumlah 20 Pemain Klub Bolavoli IKIP Budi Utomo.

Pengumpulan data yang dilakukan menggunakan instrument antara lain: angket analisisis kebutuhan, lembar validasi ahli bolavoli, lembar validasi ahli media, angket tanggapan yang dibagikan kepada responden pemain klub bolavoli IKIP Budi Utomo.

Pengumpulan data melalui tahap-tahap antara lain: penyebaran angket analisis kebutuhan ke pemain klub bolavoli IKIP Budi Utomo, analisis program latihan yang dilakukan oleh pelatih Klub IKIP Budi Utomo, mengidentifikasi kelemahan program latihan yang dilakukan sebelumnya, pengumpulan Materi Model Latihan sebelum dilakukan penyusunan, proses validasi oleh ahli Bolavoli dan Ahli Media serta Pengisian angket oleh responden Pemain Klub Bolavoli IKIP Budi Utomo.

Hasil penghitungan data yang diperoleh dari penghitungan statistik deskripsif dirujuk menggunakan kriteria (tabel 1) sehingga kelayakan model latihan dapat diketahui. 
Tabel 1. Analisis Persentase Hasil Evaluasi Subjek Uji Coba

\begin{tabular}{ccc}
\hline Skala (\%) & Keterangan & Makna \\
\hline $85-100$ & Valid & Digunakan \\
$65-84$ & Cukup Valid & Digunakan \\
$45-64$ & Kurang Valid & Diganti \\
$0-44$ & Tidak Valid & Diganti \\
\hline
\end{tabular}

(Modifikasi: Ardyanto, Winarno, \& Adi, 2016)

\section{HASIL DAN PEMBAHASAN}

\section{Deskripsi Desain Awal Model Latihan}

Hasil desain yang dilakukan pada awalnya menghasilkan 14 Model Latihan Pasing Bawah, Terdiri atas 10 Model Latihan Pasing ke sasaran keranjang tanpa melewati atas net dan 4 Model Latihan pasing ke sasaran keranjang melewati atas net. Dari desain awal kemudian dimasukkan pada tahap pengembangan untuk menghasilkan produk yang siap diimplementasikan. Fase pengembangan (development), adalah persiapan bahan model evaluasi yang direvisi dan diujicobakan melalui beberapa tahap (Winaryati, Handarsari, \& Fathurohman, 2012). Semua model dilakukan dengan pola gerak sesuai dengan gerak dasar permainan bolavoli yaitu gerak dasar maju, mundur, bergeser ke kanan dan ke kiri, sambil menempati posisi dengan tanda untuk melakukan pasing bawah ke sasaran keranjang.

\section{Hasil Validasi Ahli Terhadap Model Latihan}

Model Latihan melalui proses validasi materi bolavoli dan media yang melibatkan Ahli Materi (Pelatih Bolavoli) dan Ahli Media. Hasil validasi tiap validator yang berupa persentase kelayakan model latihan, kemudian kelayakan produk ditentukan dengan persentase total dari semua validator. Berikut disajikan hasil validasi Ahli Materi (Ahli Bolavoli) dan Ahli Media terangkum dalam tabel 2.

Tabel 2. Hasil Validasi Produk oleh Ahli Materi dan Media

\begin{tabular}{ccc}
\hline Aspek Validasi & Hasil Validasi & Keterangan \\
\hline Materi & $87,75 \%$ & Layak digunkan dengan predikat Valid \\
\hline Media & $94,75 \%$ & Layak digunakan dengan predikat Valid \\
\hline
\end{tabular}


Nilai yang diperoleh dari validator selain berbentuk persentase kelayakan juga berupa saran perbaikan model latihan yang terangkum dalam tabel 3.

Tabel 3. Saran Ahli Terhadap Model Latihan

\begin{tabular}{ll}
\hline Validator & \multicolumn{1}{c}{ Uraian Saran } \\
\hline Ahli Media & Gambar pola model latihan supaya \\
& diperjelas polanya. \\
& Tidak hanya deskripsi, namun dalam \\
& produk model supaya dilengkapi legenda \\
& yang menjelaskan setiap bagian dari \\
& gambar \\
\hline & Diameter sasaran keranjang agak dikurangi \\
& mengingat responden adalah pemain \\
& bepengalaman untuk meningkatkan akurasi \\
& pasing \\
& Model Latihan 4,7 sebaiknya ditiadakan \\
& karena pola pergerakan hampir sama \\
& dengan model 2 dan 6 \\
Ahli Materi & Pelempar bola usahakan bukan dari teman \\
& sesama pemain, melainkan ada driller \\
& sendiri supaya kedatangan bola konsisten. \\
\hline
\end{tabular}

Berdasarkan hasil validasi ahli diatas maka dilakukan revisi produk pertama diantaranya mengurangi jumlah model latihan dari semula berjumlah 14 model menjadi 12 model, pengurangan dilakukan pada model latihan 4 dan 7 yang ditiadakan. 12 Model yang telah divalidasi dan telah direvisi tersaji dalam tabel 4 berikut:

Tabel 4. Produk 12 Model Latihan Pasing Bawah

\begin{tabular}{l} 
Gambar Model \\
\hline Model 1 \\
- Pelempar bola berdiri di sebelah keranjang yang \\
terletak di atas garis tengah lapangan (posisi $\mathrm{A}$ ) \\
- Pemain berbaris dibelakang garis serang \\
menghadap lurus ke keranjang bola (posisi $\mathrm{C}$ ). \\
- Pelempar bola melemparkan bola menggunakan \\
kedua tangan kepada pemain paling depan \\
Pemain melakukan pasing dari belakang garis \\
serang mengarahkan bola ke dalam keranjang.
\end{tabular}


- Setelah melakukan pasing pemain bergeser mundur ke urutan belakang, pemain berikutnya menyusul.

- Pelempar bola berdiri di sebelah keranjang yang terletak di atas garis tengah lapangan (posisi A).

Model 2

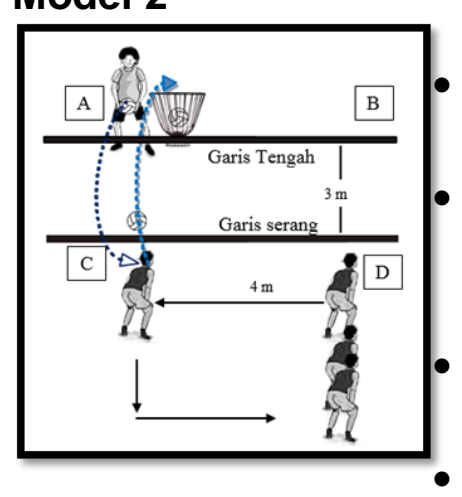

- Pemain berbaris pada sisi kanan lapangan di belakang garis serang (posisi $D$ )

Pemain paling depan bergeser sambil jongkok ke arah kiri menuju posisi $\mathrm{C}$

Pelempar bola melemparkan bola menggunakan kedua tangan kepada pemain yang telah siap di posisi $\mathrm{C}$.

Pemain melakukan pasing dari belakang garis serang mengarahkan bola ke dalam keranjang.

- Setelah melakukan pasing pemain mundur kemudian bergeser ke kanan menuju urutan belakang (Posisi D)

- Pelempar bola berdiri di sebelah keranjang yang terletak di atas garis tengah pada posisi $B$

Model 3

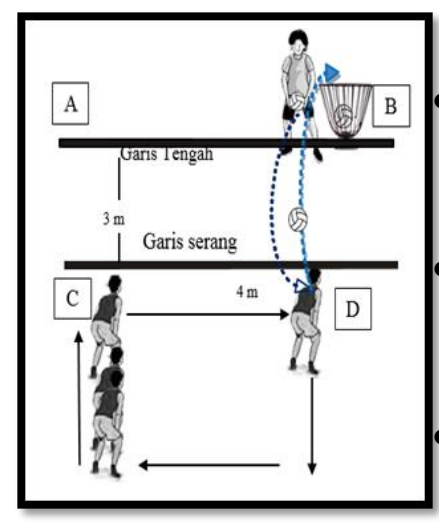

- Setelah melakukan pasing pemain mundur kemudian bergeser ke kanan menuju urutan belakang.

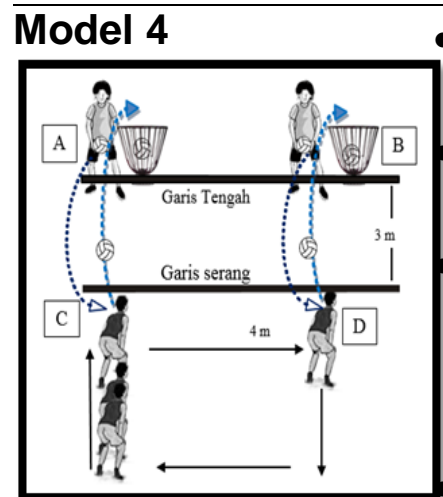

- Pemain berbaris pada sisi kiri lapangan dibelakang garis serang (posisi C)

Pemain paling depan bergeser sambil jongkok ke arah kanan sambil jongkok hingga lurus dengan keranjang bola (posisi $\mathrm{D}$ )

Pelempar bola melemparkan bola menggunakan kedua tangan kepada pemain yang telah siap pada posisi D.

Pemain melakukan pasing dari belakang garis serang mengarahkan bola ke dalam keranjang.

- Terdapat dua Pelempar bola dan dua keranjang pada posisi A dan B

Pemain berbaris pada sisi kiri lapangan di belakang garis serang (posisi $\mathrm{C}$ )

Pelempar posisi A melakukan lemparan bola ke pemain yang siap di posisi $C$ dan Pelempar posisi B melakukan lemparan bola ke pemain yang siap di posisi D.

Pemain melakukan dua kali pasing pada posisi C 


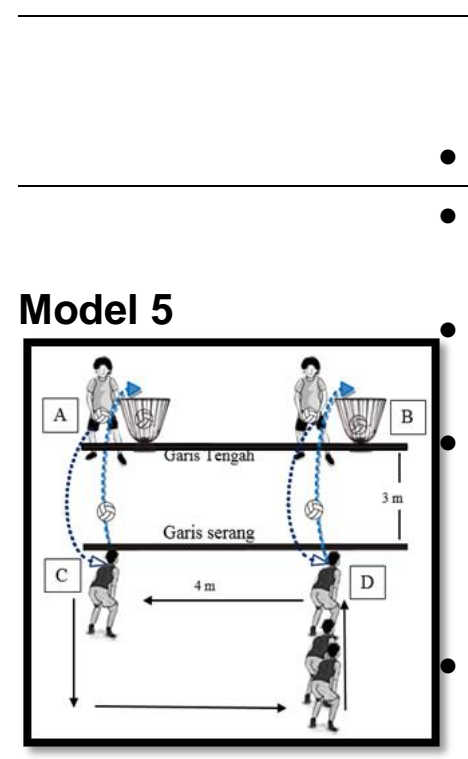

ke keranjang $A$ dan dari posisi $D$ ke arah keranjang $B$

- Arah pergeseran pemain sama dengan Model 3.

- Terdapat dua Pelempar bola dan dua keranjang pada posisi $A$ dan $B$

Pemain berbaris pada sisi kanan lapangan di belakang garis serang (posisi D)

Pelempar posisi A melakukan lemparan bola ke pemain yang siap di posisi $\mathrm{C}$ dan Pelempar posisi B melakukan lemparan bola ke pemain yang siap di posisi $D$.

Pemain melakukan dua kali pasing dari posisi D ke arah keranjang $B$ dan dari posisi C ke keranjang A.

- Arah pergeseran pemain sama dengan Model 2.

- Terdapat dua Pelempar bola dan dua keranjang

\section{Model 6}

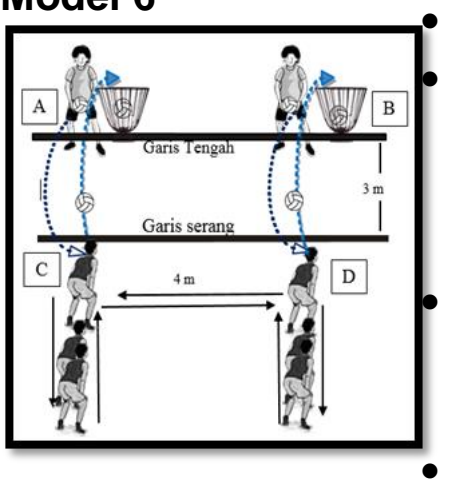
pada posisi $A$ dan $B$

Terdapat dua baris Pemain pada posisi C dan D

Pelempar posisi A melakukan lemparan bola ke pemain yang siap di posisi $\mathrm{C}$ dan Pelempar posisi B melakukan lemparan bola ke pemain yang siap di posisi D.

Setelah melakukan pasing pertama, pemain posisi $C$ dan $D$ bertukar tempat untuk melakukan pasing ke dua,

Setelah meakukan pasing dua kali pemain mundur pada urutan belakang dilanjutkan oleh pemain berikutnya.

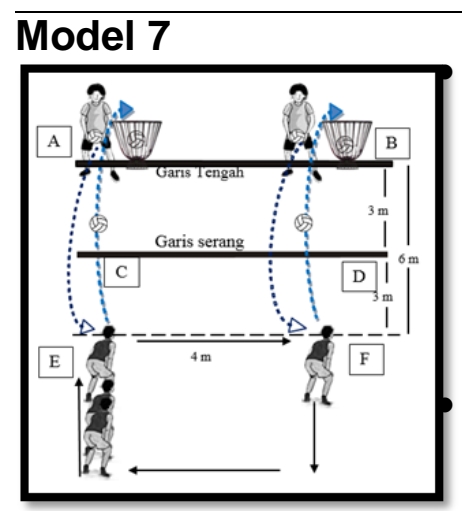

Pada prinsipnya model 7 arah pergerakan pemain, posisi pelempar dan posisi keranjang sama dengan Model 4, yang membedakan adalah posisi pemain saat melakukan pasing pada posisi yang semula berjarak 3 meter dari garis tengah menjadi berjarak 6 meter pada posisi $\mathrm{E}$ dan $\mathrm{F}$ Penambahan jarak untuk meningkatkan tantangan akurasi pasing pemain.

- Pada prinsipnya model 8 arah pergerakan Model 8 pemain, posisi pelempar dan posisi keranjang sama dengan Model 5, yang membedakan adalah posisi pemain saat melakukan pasing pada posisi 

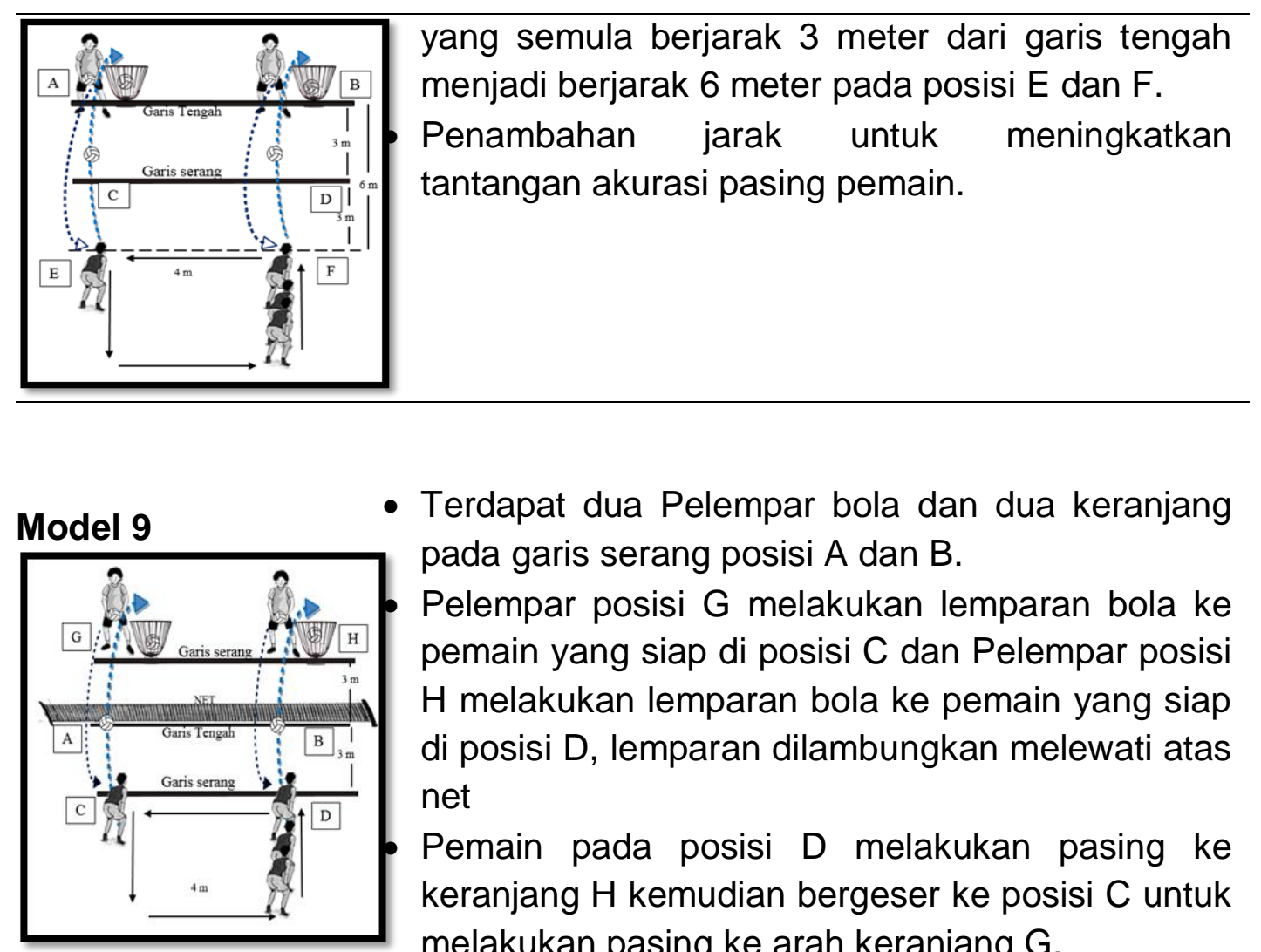

- Terdapat dua Pelempar bola dan dua keranjang pada garis serang posisi $A$ dan $B$.

Pelempar posisi $G$ melakukan lemparan bola ke pemain yang siap di posisi $C$ dan Pelempar posisi $\mathrm{H}$ melakukan lemparan bola ke pemain yang siap di posisi $\mathrm{D}$, lemparan dilambungkan melewati atas net

Pemain pada posisi D melakukan pasing ke keranjang $\mathrm{H}$ kemudian bergeser ke posisi $\mathrm{C}$ untuk melakukan pasing ke arah keranjang $\mathrm{G}$.

- Arah pergeseran pemain sama dengan model 5.

- Terdapat dua Pelempar bola dan dua keranjang

\section{Model 10}

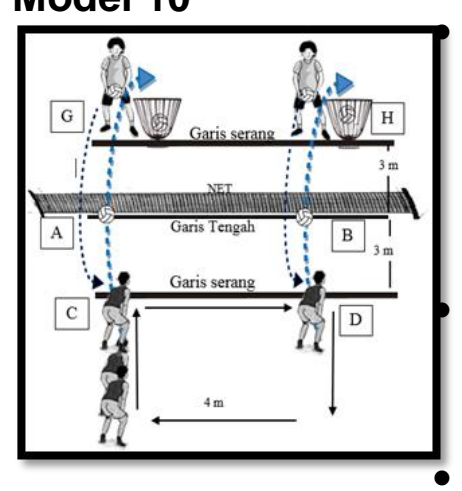
pada garis serang posisi $A$ dan $B$.

Pelempar posisi $G$ melakukan lemparan bola ke pemain yang siap di posisi $C$ dan Pelempar posisi $\mathrm{H}$ melakukan lemparan bola ke pemain yang siap di posisi $\mathrm{D}$, lemparan dilambungkan melewati atas net

Pemain pada posisi D melakukan pasing ke keranjang $\mathrm{H}$ kemudian bergeser ke posisi $\mathrm{C}$ untuk melakukan pasing ke arah keranjang $\mathrm{G}$.

Arah pergeseran pemain sama dengan model 4 (kebalikan dari model 10).

- Pelempar posisi G melakukan lemparan bola ke pemain yang siap di posisi $C$ dan Pelempar posisi $\mathrm{H}$ melakukan lemparan bola ke pemain yang siap di posisi $\mathrm{D}$, lemparan dilambungkan melewati atas

Model 11 net

- Pemain posisi C maju menyentuh Net pada posisi $A$ kemudian kembali ke posisi $C$ dengan langkah mundur untuk melakukan pasing (tidak boleh berbalik badan), demikian juga dengan Pemain 


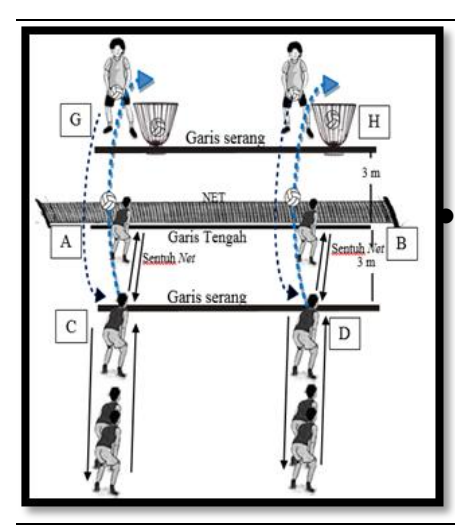

posisi D maju menyentuh Net pada posisi $B$ kemudian kembali ke posisi $D$ dengan langkah mundur untuk melakukan pasing.

Pemain posisi $C$ dan $D$ setelah melakukan pasing bergeser mundur dilanjutkan pemain yang berikutnya.

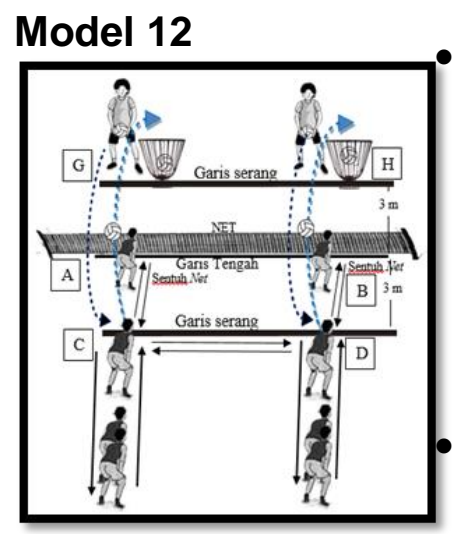

- Pelempar posisi G melakukan lemparan bola ke pemain yang siap di posisi $C$ dan Pelempar posisi $\mathrm{H}$ melakukan lemparan bola ke pemain yang siap di posisi $\mathrm{D}$, lemparan dilambungkan melewati atas net

Pemain posisi C maju menyentuh Net pada posisi $A$ kemudian kembali ke posisi $C$ dengan langkah mundur untuk melakukan pasing (tidak boleh berbalik badan), demikian juga dengan Pemain posisi D maju menyentuh Net pada posisi $B$ kemudian kembali ke posisi $D$ dengan langkah mundur untuk melakukan pasing pertama.

Setelah melakukan pasing pertama pemain posisi C dan D bertukar tempat kemudian melakukan pasing ke dua.

- Pemain posisi C dan D setelah melakukan pasing bergeser mundur dilanjutkan pemain yang berikutnya.

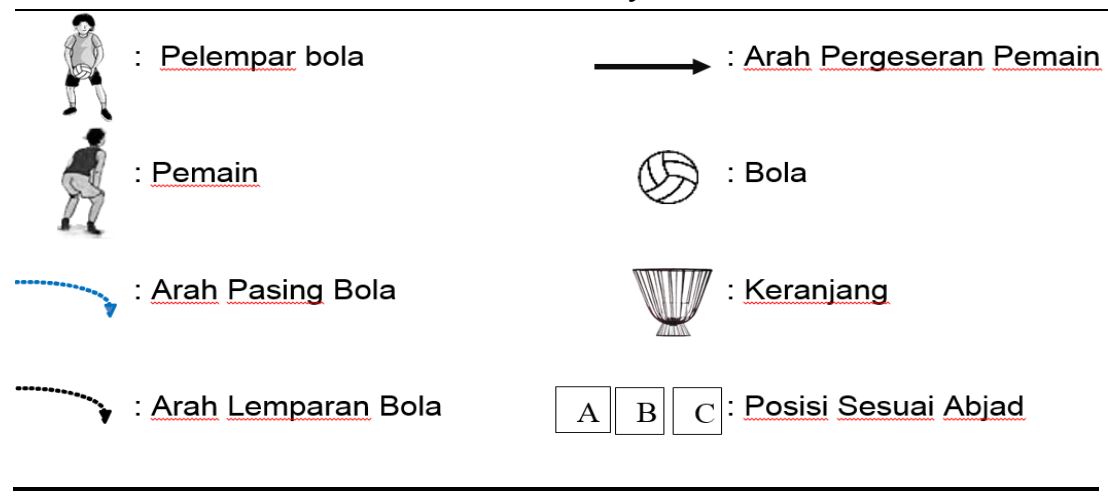

\section{Hasil Uji Lapangan}

Tahap uji lapangan meliputi uji kelompok kecil dengan responden terbatas, selanjutnya dilakukan uji kelompok besar dengan jumlah responden yang lebih banyak, hal ini untuk memperoleh masukan sebagai 
pertimbangan revisi produk akhir dan mengetahui efektifitas produk. Uji coba dilakukan pada kelompok yang lebih luas untuk mengetahui efektifitas produk yang dikembangkan dan memperoleh masukan untuk melakukan revisi produk tahap akhir (Fannie \& Rohati, 2014). Data yang diperoleh dari uji lapangan berupa data kuantitatif dari pengisian angket oleh responden Pemain Tim. Analisis data kuantitatif adalah kegiatan setelah data dari keseluruhan responden atau sumber data lain terkumpul (Sugiyono, 2010). Selanjutnya dihitung dengan penghitungan statistik persentase pada setiap model latihan, selanjutnya dilakukan penghitungan persentase keseluruhan menghasilkan data yang tersaji dalam tabel 5 dan 6 Berikut:

Tabel 5. Hasil Evaluasi Subjek Uji Kelompok Kecil $(n=8)$

\begin{tabular}{ccc}
\hline Model Latihan & Hasil & Keterangan \\
\hline 1 & $82,81 \%$ & Valid \\
2 & $78,13 \%$ & Valid \\
3 & $78,13 \%$ & Valid \\
4 & $90,63 \%$ & Valid \\
5 & $79,69 \%$ & Valid \\
6 & $90,63 \%$ & Valid \\
7 & $90,63 \%$ & Valid \\
8 & $93,75 \%$ & Valid \\
9 & $92,19 \%$ & Valid \\
10 & $95,31 \%$ & Valid \\
11 & $90,63 \%$ & Valid \\
12 & $89,06 \%$ & Valid \\
\hline Rata-rata & $\mathbf{8 7 , 6 3 \%}$ & Layak digunakan dengan predikat \\
& & Valid \\
\hline
\end{tabular}

Tabel 6. Hasil Evaluasi Subjek Uji Kelompok Besar $(n=20)$

\begin{tabular}{ccc}
\hline Model Latihan & Hasil & Keterangan \\
\hline 1 & $93,75 \%$ & Valid \\
2 & $92,19 \%$ & Valid \\
3 & $95,31 \%$ & Valid \\
4 & $90,63 \%$ & Valid \\
5 & $89,06 \%$ & Valid \\
6 & $90,63 \%$ & Valid \\
7 & $90,63 \%$ & Valid \\
8 & $87,50 \%$ & Valid \\
9 & $85,94 \%$ & Valid \\
\hline
\end{tabular}




\begin{tabular}{ccc}
10 & $95,31 \%$ & Valid \\
11 & $90,63 \%$ & Valid \\
12 & $95,31 \%$ & Valid \\
\hline Rata-rata & $\mathbf{9 1 , 4 1 \%}$ & Layak digunakan dengan predikat \\
& & Valid \\
\hline
\end{tabular}

Validasi oleh ahli materi bolavoli dan media menunjukkan produk Model Latihan Bolavoli layak digunakan dan diterapkan dalam latihan di klub Bolavoli IKIP Budi Utomo Malang. Dari sisi materi yang tedapat pada tiap model termasuk latihan yang mudah dilakukan namun memiliki tantangan dan tingkat kesenangan yang bagus karena setiap pemain dapat langsung mengukur kemampuan masing-masing dan membandingkannya dengan kemampuan pemain yang lain, tentunya dapat digunakan sebagai permainan perlombaan untk memperoleh nilai terbanyak. Ilustrasi sudah sangat jelas sehingga pemain mudah memahami dalam mempelajari model yang dikembangkan.

Hasil penilaian oleh validator ahli yang juga berupa saran tertulis (tabel 3) digunakan sebagai acuan tahap revisi terhadap model latihan bolavoli, sedangkan pada tahap uji lapangan oleh responden mahasiswa tidak timemukan adanya saran perbaikan pada produk sehingga langkah pengembangan ke 7 (revisi produk akhir) tidak dilaksanakan, perhitungan data validasi ahli dan uji lapangan diperoleh predikat valid dengan penjelasan produk dapat digunakan.

Peneliti dalam melakukan penelitian hanya sebatas mengembangkan 12 model latihan pasing bawah, terdiri atas 8 model latihan pasing ke sasaran keranjang tanpa melewati net dan 4 model pasing ke sasaran dengan melewati net. Diperlukan penelitian eksperimen terhadap model yang dikembangkan untuk menguji dampak dari penerapan model yang dilakukan, namun langkah tersebut belum mampu dilakukan peneliti karena keterbatasan waktu penelitian. Model-model yang dikembangkan tersebut didesain sedemikian rupa dengan tujuan memperbaiki kesiapan pemain dalam menyongsong datangnya bola dari lawan untuk kemudian dilakukan pasing, arah pasing yaitu memasukkan bola ke dalam keranjang sasaran dimaksudkan untuk melatih akurasi 
pasing pemain kepada teman pengumpan dalam satu tim agar dapat melakukan rangkaian serangan yang baik pula.

Rangkaian serangan yang tidak mudah dilakukan dalam permainan bolavoli menunjukkan betapa pentingnya penguasaan teknik dasar oleh tiap-tiap individu pemain dalam tim. Teknik dasar bolavoli merupakan unsur yang sangat penting dalam permainan bolavoli, tanpa penguasaan teknik dasar yang baik, maka permainan tidak dapat dimainkan dengan sempurna (Yudasmara, 2014). Hal yang sama dikemukakan oleh Dinata (2004) bahwa teknik dasar adalah faktor utama selain kondisi fisik, taktik, dan mental seorang pemain. Peneliti berpendapat perlu dilakukan pengembangan-pengembangan model latihan yang benar pada tiap teknik dasar dalam permainan bolavoli. pendapat ini diperkuat dengan penelitian yang dilakukan oleh Muttaqin, Winarno, \& Kuniawan (2016) Pengembangan Model Latihan Smash Bolavoli pada Kegiatan Ekstrakurikuler di SMPN 12 Malang, bahwa permainan bolavoli memerlukan model latihan yang benar dan sesuai agar dalam permainan bolavoli menghasilkan permainan yang sempurna, karena gerakan yang tidak sempurna akan menimbulkan gerakan yang salah dan mengakibatkan permainan tidak berjalan dengan baik juga. Tugas ini tidak hanya bagi pengembang permainan bolavoli dan pelatih saja, namun ini merupakan tanggungjawab bersama. Pemain sebagai individu juga harus bijak dalam menentukan model latihan yang tepat saat mereka melakukan latihan mandiri.

\section{KESIMPULAN DAN SARAN}

Kesimpulan yang dapat dikemukakan diantaranya penelitian pengambangan yang telah dilaksanakan menghasilkan 12 model latihan pasing bawah, penilaian oleh ahli materi dan ahli media terhadap model latihan diperoleh predikat valid dengan keterangan dapat digunakan, artinya produk 12 model latihan pasing bawah yang dihasilkan dapat diterapkan pada klub bolavoli IKIP Budi Utomo dan klub bola voli lain. 
Pagi para pengembang yang ingin mengembangkan model latihan disarankan untuk menyusun secara sistematis, diawali dengan pola atau pergerakan yang paling sederhana kemudian bertahap menjadi gerakangerakan yang semakin kompleks untuk melatih kemampuan pemain menguasai pola dan teknik termudah selanjutnya menjadi semakin sulit.

Pola model latihan yang dikembangkan dapat dikembangkan lagi sedemikian rupa sehingga dapat diterapkan sesuai dengan kemampuan pemain, ketersediaan media yang ada dan kondisi di lapangan.

\section{DAFTAR PUSTAKA}

Ardyanto, E. R., Winarno, M. E., \& Adi, S. (2016). Pengembangan Instrumen Pengetahuan Mata Pelajaran Pendidikan Jasmani Olahraga Kesehatan (PJOK) Untuk Siswa Kelas XII Sekolah Menengah Atas. Jurnal Pendidikan: Teori, Penelitian, Dan Pengembangan, 1(10), 1897-1903.

Dinata, M. (2004). Belajar Bolavoli. Jakarta: Cerdas Jaya.

Fannie, R. D., \& Rohati. (2014). Pengembangan Lembar Kerja Siswa (LKS) Berbasis POE (Predict, Observe, Explain) pada Materi Program Linier Kelas XII SMA. Jurnal Sainmatika, 8(1), 96-109.

Gall, M. D., Gall, J. P., \& Borg, W. R. (2007). Educational research: an introduction. Pearson/Allyn \& Bacon. Retrieved from https://books.google.co.id/books?id=3fsUSgAACAAJ\&dq=Borg+dan + Gall+(1983)\&hl=en\&sa=X\&ved=0ahUKEwjlOriBjq_bAhVXT30KHe H1APIQ6AEIKTAA

Hasmara, P. S. (2017). Upaya Meningkatkan Hasil Belajar Passing Bolavoli Menggunakan Model Pembelajaran Aktif, Inovitif, Kreatif, Efektif, dan Menyenangkan. Jurnal Bravo's, 5(4), 161-165.

Hidayat, M. T. (2015). Peningkatan Kemampuan Pass Bawah dalam Permainan Bola Voli Melalui Latihan Pass Bawah Duduk Berdiri pada Bangku dan Pass Bawah dengan Berjalan pada Siswa Kelas VI SDN Tanggul Wetan 01 Jember. Jurnal Pancaran, 4(1), 153-164.

Iskandar, \& Yulianingsih. (2015). Peningkatan Keterampilan Passing Atas dalam Permainan Bola Voli Melalui Metode Bermain Siswa Kelas VIII SMP Negeri 3 Sungai Ambawang. Jurnal Pendidikan Olahraga, 4(2), 157-169.

Muttaqin, I., Winarno, M. E., \& Kuniawan, A. (2016). Pengembangan Model Latihan Smash Bolavoli pada Kegiatan Ekstrakurikuler di SMPN 12 Malang. Jurnal Pendidikan Jasmani, 26(2), 257-272. 
Pasaribu, A. M. N. P. (2016). Pengaruh Gaya Mengajar dan Motivasi Belajar Passing Bawah dalam Permainan Bola Voli pada Siswa SMP Kelas VII Tahun 2013/2014. Jurnal SPORTIF: Jurnal Penelitian Pembelajaran, 2(2), 85-97.

Primayanti, I. (2016). Perbedaan Pengaruh Metode Latihan Plyometrik dan Berbeban terhadap Peningkatan Kecepatan Smash Bolavoli Ditinjau dari Kekuatan Otot Lengan. Jurnal Pendidikan Olahraga Dan Kesehatan "GELORA," 3 (ISSN: 2355-4355), 393-404.

Rosdiani, D. (2012). Perencanaan Pembelajaran Dalam Pendidikan Jasmani dan Kesehatan (Vol. 4). Bandung: CV. Alfabeta.

Safitri, D., \& Hartati, T. W. (2016). Kelayakan Aspek Media dan Bahasa dalam Pengembangan Buku Ajar dan Multimedia Interaktif Biologi Sel. Florea, 5(10), 6487-6516.

Sugiyono. (2010). Metode Penelitian Pendidikan: Pendekatan Kuantitatif, Kualitatif, dan R\&D. Bandung: Alfabeta.

Tauhidman, H., \& Ramadan, G. (2018). Pengembangan Model Latihan Keseimbangan Program Studi Pendidikan Jasmani Kesehatan dan Rekreasi STKIP Muhammadiyah Kuningan. Jurnal SPORTIF: Jurnal Penelitian Pembelajaran, 4(1), 134-144.

Winaryati, E., Handarsari, E., \& Fathurohman, A. (2012). Analysis Pengembangan Model Pembelajaran "Wisata Lokal" pada Pembelajaran Sains. In Seminar Hasil-Hasil Penelitian-LPPM UNNIMUS 2012. Semarang: Universitas Muhammadiyah Semarang. Retrieved from http://download.portalgaruda.org/article.php?article=4484\&val=426

Yudasmara, D. (2014). Pengembangan Model Latihan Teknik Block dalam Bolavoli. Jurnal IPTEK Olahraga, 16(1), 79-102. 